\title{
FEATURE
}

\section{Roadless areas and clean water}

\author{
Dominick A. DellaSala, James R. Karr, and David M. Olson
}

lean water, like biodiversity, is most closely linked to undisturbed natural ecosystems. When undisturbed watersheds in roadless and protected areas (e.g., national parks, state parks, wilderness areas, national monuments) are fragmented by roads, logging, and intensive recreation development, both water quality and biodiversity decline as hydrological integrity is lost (USFS 1972, 1979, 2001; Alexander and Gorte 2008; Anderson 2008). In the United States, inventoried roadless areas (IRAs) are lands without roads exceeding 2,000 ha $(5,000 \mathrm{ac})$ that have been inventoried by the USDA Forest Service. IRAs collectively amount to approximately one third of the 77 million ha (193 million ac) of the 155 national forests but are disproportionately concentrated in western states (figure 1) (Trout Unlimited 2004; Anderson 2008). The roaded, intensively managed landscapes of the other national forest lands have been closely correlated with heavily sediment-laden streams and dramatic changes in flow regimes (Espinosa et al. 1997; Trombulak and Frissell 2000; CBD et al. 2001; Coffin 2007; Frissell and Carnefix 2007). While the biodiversity benefits of IRAs are well documented (DeVelice and Martin 2001; Strittholt and DellaSala 2001; Loucks et al. 2003; Strittholt et al. 2004; Gelbardi and Harrison 2005), little has been made of the importance of IRA water for downstream users and wildlife.

In this paper, we assess the importance of IRAs from a water quality perspective, including the likely water quality effects of developing IRAs. We provide conservative estimates of the economic impact of intact unroaded watersheds on national forests for clean water and associated water resource benefits. In particular,

Dominick A. DellaSala is Chief Scientist and President of the Geos Institute, Ashland, Oregon. James R. Karr is professor emeritus of ecology and environmental policy at the University of Washington, Seattle, Washington. David M. Olson is a conservation biologist at the Conservation Earth Consulting, Burbank, California. rising demand and shrinking water supply associated with changing climate will likely make intact areas in drought-prone regions of the West even more valuable and crucial to protect. Thus, our findings are especially relevant to drought-prone states considering development of IRAs. The state of Colorado, for example, with approximately 1.7 million ha (4.2 million ac) of IRAs, has been seeking federal permission to develop its IRAs for logging, expanding ski areas, coal-bed mining, and producing oil and gas (figure 2) (Anderson 2008; Colorado Division of Wildlife 2010; Colorado, State of 2010; Straub 2010, USFS 2011). Although we focus on IRAs throughout the western United States, we also emphasize the importance of uninventoried roadless areas (unroaded) <2,000 ha (Henjum et al. 1994; Greenwald 1998; Beschta et al. 2004) that collectively cover an area roughly 1.5 times that of the total IRA network (USFS 2000; Strittholt et al. 2004). Those smaller unroaded areas also play a strategic role in maintaining reliable

\section{Figure 1}

Federal inventoried roadless areas (IRAs) of the United States (Source: USDA Forest Service).

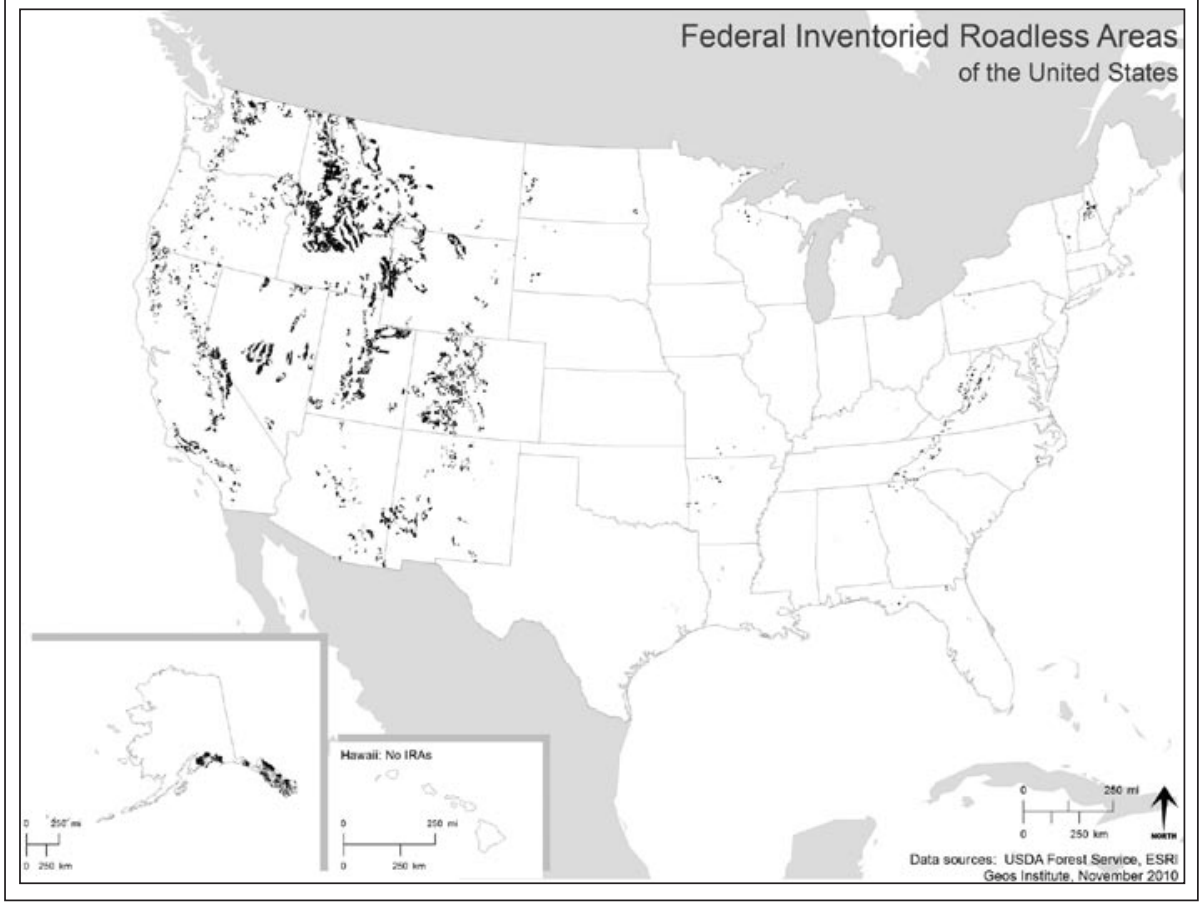

supplies of high-quality water and protecting aquatic ecosystems.

\section{ROADLESS AREAS PROVIDE SUBSTANTIAL WATER RESOURCE BENEFITS}

IRAs benefit society in many ways, including providing a valuable and increasingly rare natural supply of abundant, clean, and naturally reliable water (Sedell et al. 2000); affordable drinking water for municipal and rural communities; water for agricultural and industrial uses; flood control; instream aquatic recreation; aquifer recharge; flood protection; reliable water supply; diverse and productive fisheries; healthy aquatic ecosystems; resident and migratory waterfowl habitat; recovery of endangered species; and, increasingly, the vitality and sustainability of local economies (table 1). These benefits accrue nationally and at the local and regional levels.

National Benefits of Clean RoadlessArea Water. At least 124 million Americans directly benefit from water 
originating from national forests (Sedell et al. 2000). In fact, national forests provide about $15 \%$ of the nation's runoff with an estimated net value of $\$ 3.7$ (Sedell et al. 2000 ) to $\$ 27$ billion (Krieger 2001). The water treatment value alone of National Forests ranges from $\$ 490$ million (Loomis 2005 ) to $\$ 18$ billion (Krieger 2001).

Because IRAs represent roughly a third of national forestland, by inference they contribute significantly to the overall runoff volume and value (Anderson 1997, 2008) estimated in billions of dollars annually (Loomis and Richardson 2001; Sechhi et al. 2005). For instance, using Forest Service data (USFS 2000), IRAs make up 661 of the 914 national forest watersheds, with $55 \%$ of the 914 watersheds acting as source areas for facilities that treat and distribute drinking water to the public. The cost-savings to water treatment plants and highway departments from avoiding sedimentation caused by logging in IRA watersheds is estimated at up to $\$ 18$ billion annually (Loomis 1988). IRAs provide $\$ 490$ million annually in waste treat-

\section{Figure 2}

Colorado's 2001 inventoried roadless areas (IRAs) are shown in light gray, the 2011 proposed Colorado roadless areas (CRAs) are shown in gray, and overlap between CRAs and IRAs is shown in black. Water quality will be most impacted by changes of allowable activities within existing IRAs relative to changes in designated areas (USFS 2011).

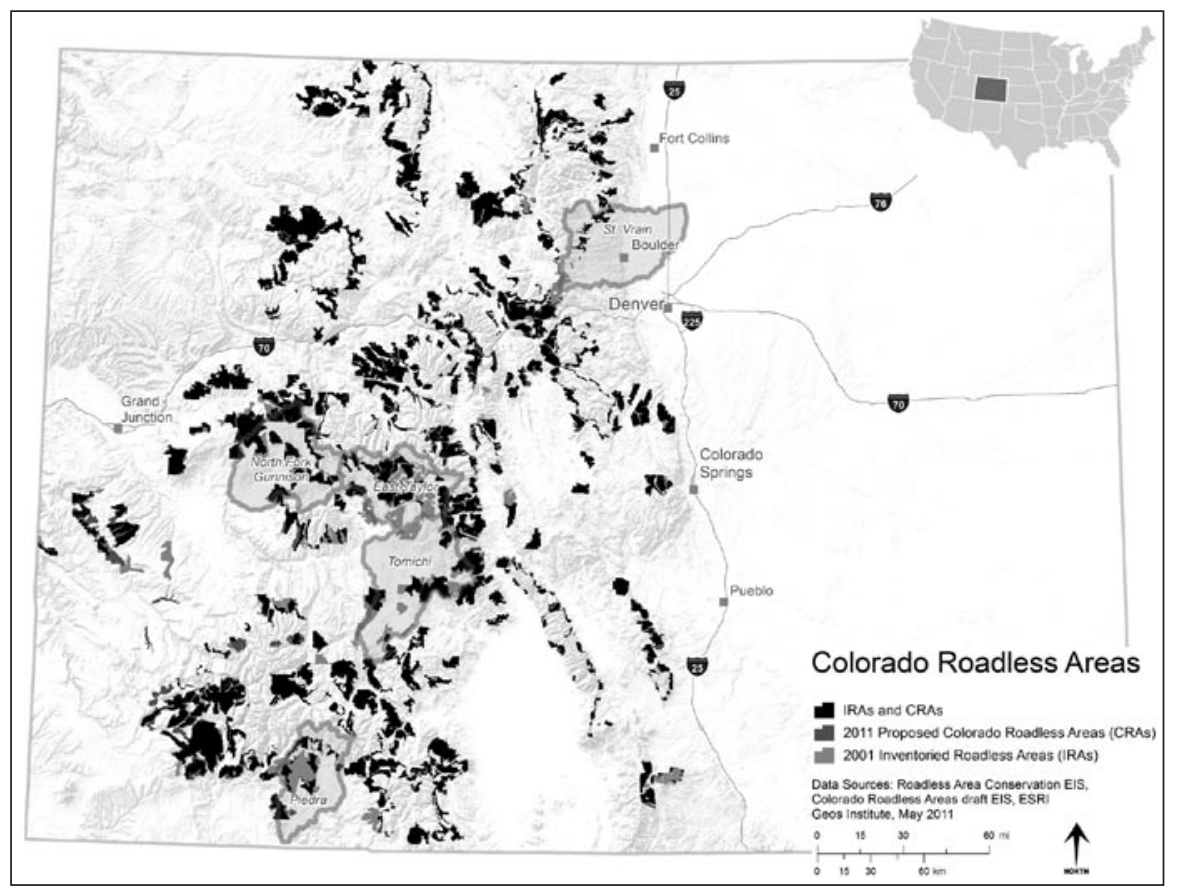

\section{Table 1}

General ecosystem services and benefits related to water that are provided by undisturbed IRAs and watersheds (derived from Greenway 1996; Costanza et al. 1997; Talberth and Moskowitz 1999; GAO 2000; Heal 2000, Loomis and Richardson 2001; Sedell et al. 2000; Krieger 2001; Dombeck 2003; Berrens et al. 2006).

\begin{tabular}{|c|c|}
\hline & Benefits \\
\hline Off-stream benefits & $\begin{array}{l}\text { Low treatment costs for water for all beneficiaries } \\
\text { Low price per unit volume costs for water for all beneficiaries } \\
\text { High-quality and abundant drinking water for rural communities and municipal water supplies } \\
\text { High-quality water for agricultural and industrial purposes } \\
\text { High-quality water for downstream livestock production } \\
\text { High-quality water for reduced health care and epidemic control } \\
\text { Reduced costs of flood damage and flood control; enhanced local economies and property values } \\
\text { Community benefits, including jobs, income, favorable trends for key economic indicators, and economic sustainability } \\
\text { and stability } \\
\text { Recharging of groundwater aquifers } \\
\text { Healthy terrestrial and riparian ecosystems and their component species, sustained ecological and evolutionary processes, } \\
\text { and resilient ecosystems }\end{array}$ \\
\hline In-stream benefits & $\begin{array}{l}\text { Healthy aquatic ecosystems } \\
\text { Recovery of endangered species and protection of refugia } \\
\text { Diverse and productive fisheries } \\
\text { High-quality habitat for wildlife, including migratory waterfowl and game and nongame species } \\
\text { Aquatic recreation such as swimming, rafting, and boating; enhancement of hiking and camping } \\
\text { The inherent value of wild rivers and wilderness (including passive use benefits such as option, bequest, and existence values) } \\
\text { Moderation of runoff and streamflows (e.g., lower peak flows, higher low flows, year-round water) } \\
\text { Soil stabilization and erosion control } \\
\text { Scientific value (intact watersheds are very rare today) } \\
\text { Maintaining sediment production to streams at normal background rates } \\
\text { Reducing potential for damage to downstream properties and water users during periods of high flow } \\
\text { Breakdown and containment of waste and toxins (e.g., atmospheric, prior use) }\end{array}$ \\
\hline
\end{tabular}


ment services through recovering mobile nutrients and cleansing the environment, both processes that involve water flow through intact watersheds (Loomis and Richardson 2001).

Regional Benefits of Clean RoadlessArea Water. In the US Rocky Mountains, roughly one third of utilized streamflow is derived directly from IRAs (which cover a quarter of Colorado's headwaters), with cities like Denver receiving about 30\% of their water supply from IRA watersheds. Annually, IRAs in Colorado are estimated to provide an equivalent of nearly 2.5 times Denver's annual water use (Doyle and Gardner 2010; Denver Water 2010). Similarly, IRAs in New Mexico provide an estimated water quality benefit up to $\$ 42$ million annually (Berrens et al. 2006).

Flood Control Protection and Inventoried Roadless Areas. The intact watersheds of IRAs are especially important for ameliorating the frequency and intensity of flooding, saving millions of dollars annually from averted floods and associated sedimentation, a service that will only increase in value as climate change drives more floods (Seeds 2010). Dredging reservoirs to increase capacity and channels to enable navigation costs cities, states, and ultimately taxpayers millions annually. Salem, Oregon, spent approximately $\$ 100$ million on new treatment facilities after logging in upper watersheds created conditions leading to mass sedimentation in its watershed following storms in 1996 (Schwickert and Mauldin 1997; Talberth and Moskowitz 1999). In addition, Seattle, Washington, deferred a $\$ 150$ million filtration plant expenditure through an intensive watershed rehabilitation program that will decommission $480 \mathrm{~km}$ (300 mi) of roads over a 10 -year period, fix road erosion problems, and limit access and high-risk activities for fire and sedimentation within their watersheds (Seeds 2010).

Recreation Benefits and Strong Local Economies. IRA water benefits outdoor recreation and the people that either engage in or earn their living from outdoor recreation. The nation's IRAs generate $\$ 600$ million annually from recreation (Loomis and Richardson 2001). Passive-use values (i.e., the intrinsic value of wilderness, wildlands, and benefits for the future) are estimated at an additional $\$ 280$ million annually. At the regional scale, New Mexico IRA water provides an estimated $\$ 27$ million active outdoor recreation benefit and a $\$ 14$ million passive-use benefit annually (Berrens et al. 2006). For many visitors, much of the attraction to wildlands is associated with the presence of clean and abundant water-a dwindling resource as logging, grazing, and road-building continues across mountain landscapes and droughts from a changing climate intensify in much of the West (Saunders et al. 2008).

Freshwater Biodiversity and Healthy Fisheries. Clean water from IRAs also maintains healthy fisheries, such as salmon and trout fisheries, sustains viable aquatic ecosystems, and helps protect threatened species and ecosystems (Abell et al. 2000; Trout Unlimited 2004). Indeed, IRAs may act as important refugia for many salmon and trout populations, as well as for a diversity of endangered freshwater species (Henjum et al. 1994; Huntington 1998; NRC 1996; Trombulak and Frissell 2000; CBD et al. 2001; Strittholt and DellaSala 2001; Oechsli and Frissell 2002; Strittholt et al. 2004; Petersen 2005). Restoration of salmon and trout fisheries in places with high road densities will likely fail without the pivotal role provided by IRAs as fishery strongholds.

\section{ROADLESS AREAS ARE IMPORTANT

SOURCES FOR DRINKING WATER

The distribution of IRAs across prime hydrologic real estate-headwaters and upper watersheds-makes them particularly valuable for providing reliable supplies of clean water. In Colorado, IRAs occur in the headwaters of all major drainages, covering roughly a third of upper watersheds in the state. Indeed, most IRAs are located in mountainous terrain in western states, including Oregon, Idaho, New Mexico, Utah, Montana, California, and Washington. This extensive coverage of IRAs in headwaters, and because they are often the last minimally disturbed watersheds within larger landscapes of degraded lands, makes them hydrologic hotspots - areas with relatively small spatial extent that have a disproportionately important role in producing abundant and reliable clean water (Frissell and Carnefix 2007).

For many major drainages (entire watersheds of major rivers, such as the Columbia River Basin), IRAs and other wilderness areas represent the last few percentages (typically $1 \%$ to $5 \%$ ) of the landscape with a minimally disturbed, or near natural, hydrology. As in many other ecological contexts, losing the last relatively natural systems typically results in major losses in water resource benefits, losses that can only be compensated by very expensive actions. The known relationship between watershed degradation and water quality decline deserves to be more rigorously incorporated as a central foundation for decisions on watershed management and protection.

Developing Roadless Areas Degrades Water Quality. In addition to their keystone location within watersheds, roadless areas typically encompass the most fragile of natural landscapes-montane forests and meadows. Road building and other intensive management in these otherwise intact areas damage their ability to provide clean water for downstream communities and biodiversity over both short and long terms (Beschta 1978; Forman and Alexander 1998; Lugo and Gucinski 2000; Trombulak and Frissell 2000; Gucinski et al. 2001; Coffin 2007). Logging, including post-disturbance, fire-risk reduction, forest health, and insect control; livestock grazing; mining; and road building are responsible for chronic and acute sedimentation of aquatic ecosystems, alter overland flow and stream structure, and change a range of physical and biological features by causing more frequent and intense floods, decreasing available water throughout the year, increasing stream and ambient temperatures, and elevating turbidity and nutrient levels (Beschta 1978; Fleischner 1994; Trombulak and Frissell 2000; DellaSala et al. 2006; Coffin 2007). Logging roads have been linked to great increases in erosion rates and sediment delivery to streams-up to $850 \%$ over rates in undisturbed habitat - with longterm and often catastrophic impacts on stream biota, aquatic ecosystems, and water quality (Fredricksen 1970; Megahan and Kidd 1972; Amaranthus et al. 1985; Bilby 
et al. 1989; King 1989, 1993; Haynes and Horne 1997; Jones et al. 2000; Wemple and Jones 2003).

Depending on severity and duration of impacts, disturbance can elevate average turbidity levels well above background levels (Seeds [2010] provides examples from Oregon), along with triggering more frequent and intense turbidity spikes that are a major source of excess costs to municipal water supply departments. Relative to roadless watersheds with intact natural vegetation, intensively managed watersheds also produce less available water (i.e., average monthly usable raw water) due to intensified high flows with very high turbidity and exacerbated low flow conditions (Seeds 2010). The monthly reliability of water is also diminished.

Even small disturbances in upper watersheds can result in significant, cumulative, and long-term impacts to downstream water and aquatic ecosystems (Platts and Nelson 1985; Boise National Forest 1993; McIntosh et al. 1994, 1995). In unstable terrain, for instance, small areas (e.g., less than $10 \%$ of a watershed's area) of lowintensity disturbance, including roads, may greatly increase the frequency and size of mass erosion events, with subsequent acute and chronic reduction in downstream water quality. Management activities that damage natural vegetation typically result in loads of suspended solids that exceed background levels and more frequent and intense spikes in suspended solids stemming from an increase in mass erosion events like landslides, debris flows, and bank failures. These impacts are strongly correlated with roads, as well as with logging and grazing (Amaranthus et al. 1985; Fleischner 1994; Trombulak and Frissell 2000; Coffin 2007).

Rising Demand and Climate Change Diminish Water Supply. Population in the West is projected to increase by $300 \%$ within just 30 years, with similar increases in demand for water (Sedell et al. 2000). Urban and exurban areas are growing exponentially, including communities adjacent to wilderness areas and IRAs (Theobald 2005). The demand for water in Colorado is expected to triple by 2050 . Similarly, the number of people relying on national forest water has dou- bled in Oregon in the last 30 years, and $86 \%$ of the population of Washington rely on national forest water to some degree (Sedell et al. 2000).

The dramatic population growth in the West is concurrent with a warming and drying climate in many places. Temperatures are increasing, snow pack is declining and melting sooner, and drought and summer water deficits are more frequent and longer (Barnett et al. 2008; Mohammed and Tarboton 2008; Saunders et al. 2008; Miller et al. 2010). Streamflow reductions ranging from 10\% to 35\% are likely for the western states over the next half century as a consequence of climate change (Barnett and Pierce 2009). A 10\% drop in streamflow is considered calamitous by municipal water districts. More frequent and intense flood events are also likely in places (Raff et al. 2009), despite drying conditions. Costs for flood control, repair and reconstruction, and insurance rates will also increase (GAO 2007). These events will worsen the severe and unprecedented droughts already afflicting much of the West (Drechsler et al. 2006; Saunders et al. 2008).

\section{SOLUTION: A LIGHT HYDROLOGICAL FOOTPRINT IN ROADLESS AREAS}

IRAs should be managed in the same way many municipalities manage their watersheds-sustaining a light ecological and hydrological footprint and hydrologic restoration through decommissioning or, even better, obliteration of roads (Barten et al. 1998; NRC 2000; Payne et al. 2004; Gallo et al. 2005; Postel and Thompson 2005; Seeds 2010). The most cost-effective and prudent approach to maintain water supplies and high-quality fresh water in the face of population growth and climate change is to manage upper watersheds in a roadless condition with undisturbed natural vegetation. The high, long-term economic cost of degrading clean water for millions of people, by itself, is argument strong enough to continue protection of the current roadless areas network either at national or state levels. Development of IRAs, as proposed in Colorado, would primarily provide opportunities for short-term gains, but the substantial and long-term impacts on water quality and availability will come at a time of increasing demand and shrinking supply. Managers should, therefore, treat IRAs as natural reservoirs of high quality water for downstream users before approving development projects. Cost-benefit analyses should include regionally and locally specific estimates of water quality to better inform project management decisions that may reduce the value of high-quality water in the short and long run.

\section{CONCLUSIONS}

Roadless areas and the relatively intact ecosystems they maintain provide many important biodiversity benefits, including acting as strongholds for threatened freshwater species. Beyond these important values, their role in producing clean and reliable water for people and economies is more likely to compel decision-makers to leave roadless areas undeveloped. We reviewed the importance of inventoried roadless areas on national forests in the United States to determine their importance in providing clean water for downstream users. We concluded that (1) many intact watersheds are in headwaters, (2) they supply downstream users with high-quality drinking water, and (3) developing these watersheds comes at significant costs associated with declining water quality and availability. Several case studies from the western United States, particularly Colorado, demonstrated the importance of assessing the diverse consequences of developing roadless areas. Managers should perform comprehensive cost-benefit analyses when weighing development options. A light-touch hydrological footprint is recommended to sustain the many values that derive from roadless areas, especially clean and abundant water.

\section{ACKNOWLEDGEMENTS}

We thank the many individuals and organizations that have contributed to this evaluation. In particular, we appreciate the reviews of earlier drafts of the manuscript by Robert Beschta of Oregon State University, Corvallis, Oregon; Josh Seeds of Oregon Department of Environmental Quality, Portland, Oregon; and Linda Farley of Conservation Earth. Richard Nauman and Jessica Leonard of the Geos Institute, Ashland, Oregon, provided GIS support and review. Sponsored by a grant from The Pew 
Charitable Trusts. The opinions expressed in this report are those of the authors and do not necessarily reflect the views of The Pew Charitable Trusts.

\section{REFERENCES}

Abell, R., D. Olson, E. Dinerstein, P. Hurley, S. Walters, C. Loucks, T. Allnutt, and W. Wettengel. 2000. A Conservation Assessment of the Freshwater Ecoregions of North America. Washington, DC: Island Press.

Alexander, K., and W. Gorte. 2008. National Forest System Roadless Area initiatives. CRS Report to Congress, Order Code RL30647.

Amaranthus, M., R. Rice, N. Barr, and R. Ziemer. 1985. Logging and forest roads related to increased debris slides in southwestern Oregon. Journal of Forestry 83:229-233.

Anderson, M. 1997. Idaho's Vanishing Wild Lands: A Status Report on Roadless Areas in Idaho's National Forests. Seattle, WA: The Wilderness Society.

Anderson, M. 2008. A decade of National Forest Roadless Area Conservation: Background Paper. Seattle, WA:The Wilderness Society.

Barnett, T.P., D.W. Pierce, H.G. Hidalgo, C. Bonfils, B.D. Santer, T. Das, G. Bala, A.W. Wood, T. Nozawa, A.A. Mirin, D.R. Cayan, and M.D. Dettinger. 2008. Human-induced changes in the hydrology of the Western United States. Science 319:1080-1083.

Barnett,T.P., and D.W. Pierce. 2009. Sustainable water deliveries from the Colorado River in a changing climate. The Proceedings of the National Academy of Sciences USA 106:7334-7338.

Barnett, T.P., D.W. Pierce, H.G. Hidalgo, C. Bonfils, B.D. Santer, T. Das, G. Bala, A.W. Wood, T. Nozawa, A.A. Mirin, D.R. Cayan, and M.D. Dettinger. 2008. Human-induced changes in the hydrology of the Western United States. Science 319:1080-1083.

Barten, P.K., T. Kyker-Snowman, P.J. Lyons, T. Mahlstedt, R. O'Connor, B.A. Spencer. 1998. Massachusetts: Managing a watershed protection forest. Journal of Forestry 96:10-15.

Berrens, R., J. Talberth, J. Thacher, and M. Hands. 2006. Economic and community benefits of protecting New Mexico's Inventoried Roadless Areas. Santa Fe, NM: Center for Sustainable Economy and Forest Guardians.

Beschta, R.L. 1978. Long-term patterns of sediment production following road construction and logging in the Oregon Coast Range. Water Resources Research 14:1011-1016.

Beschta, R.L., J.J. Rhodes, J.B. Kauffman, R.E. Gresswell, G.W. Minshall, J.R. Karr, D.A. Perry,
F.R. Hauer, and C.A. Frissell. 2004. Postfire management on forested public lands of the western United States. Conservation Biology 18:957-967.

Bilby, R.E, K. Sullivan, and S.H. Duncan. 1989. The generation and fate of road-surface sediment in forested watersheds in southwestern Washington. Forest Science 35:453-468.

Boise National Forest. 1993. Biological Assessment of Bear Valley Basin Livestock Grazing Allotments-Effects on Snake River Basin Spring/ Summer Chinook Salmon. Boise, ID: Boise National Forest.

CBD (Center for Biological Diversity). 2001. Imperiled Trout and the Importance of Roadless Areas: A Report by the Western Native Trout Campaign. Tucson,AZ:The Center for Biological Diversity, Pacific Rivers Council, Biodiversity Associates.

Coffin, A.W. 2007. From roadkill to road ecology: A review of the ecological effects of roads. Journal of Transport Geography 15:396-406.

Colorado Division of Wildlife. 2010. Inventoried Roadless Areas Report 2010. http://wildlife. state.co.us/LandWater/Roadless/.

Colorado, State of. 2010. Colorado Roadless Final Petition - April 4, 2010; Subpart D-Colorado Roadless Areas Management. Denver, CO: Office of the Governor.

Costanza, R., R. d'Arge, R. de Groot, S. Farber, M. Grasso, B. Hannon, K. Limburg, S. Naeem, R.V. O’Neill, J. Paruelo, R.G. Raskin, P. Sutton, and M. van den Belt. 1997. The value of the World's ecosystem services and natural capital. Nature 387:253-260.

DellaSala, D.A., J.R. Karr, T. Schoennagel, D. Perry, R.F. Noss, D. Lindenmayer, R. Beschta, R.L. Hutto, M.E. Swanson, and J. Evans. 2006. Postfire logging debate ignores many issues. Science 314:51-52.

Denver Water. 2010. Solutions: Saving water for the future. Denver Water Newsletter 2010. Denver, CO.

DeVelice, R.L., and J.R. Martin. 2001. Assessing the extent to which roadless areas complement the conservation of biological diversity. Ecological Applications 11:1008-1018.

Dombeck, M. 2003. Water is forest's most vital product. Seattle Post-Intelligencer, January 5, 2003. http://seattlepi.nwsource.com/opinion/ 102721_forestop.shtml.

Doyle, D. and N. Gardner. 2010. Dry times. April, 2010. http://www.5280.com.

Drechsler, D., N. Motallebi, M. Kleeman, D. Cayan, K. Hayhoe, L. S. Kalkstein, N. Miller, S. Sheridan,
J. Jin, and R.A. VanCurren. 2006. Public healthrelated impacts of climate change in California. Berkeley, CA: California Climate Change Center. http://www.energy.ca.gov/2005publications/ CEC-500-2005-197/CEC-500-2005-197SF.PDF.

Espinosa, F.A., J.J. Rhodes, and D.A. McCullough. 1997. The failure of existing plans to protect salmon habitat in the Clearwater National Forest in Idaho. Journal of Environmental Management 49:205-230.

Fleischner, T.L. 1994. Ecological costs of livestock grazing in western North America. Conservation Biology 8:629-644.

Forman, R.T., and L.E. Alexander. 1998. Roads and their major ecological effects. Annual Review of Ecology and Systematics 29:207-231.

Fredricksen, R.L. 1970. Erosion and sedimentation following road construction and timber harvest on unstable soils in three small western Oregon watersheds. USDA Forest Service Research Paper PNW-104. Portland, OR: USDA Forest Service, Pacific Northwest Research Station.

Frissell, C., and G. Camefix. 2007. The geography of freshwater habitat conservation: Roadless Areas and critical watersheds for native trout. Wild Trout IX Symposium, October 2007.

Gallo, K., S.H. Lanigan, P. Eldred, S.N. Gordon, and C. Moyer. 2005. Northwest Forest Plan - The first 10 years: Preliminary assessment of the condition of watersheds. General Technical Report PNWGTR-647. Portland, OR: USDA Forest Service, Pacific Northwest Research Station.

GAO (Government Accountability Office). 2000. Forest Service Roadless Areas: Potential Impact of Proposed Regulations on Ecological Sustainability. GAO-01-47. Washington, DC: GAO.

GAO. 2007. Climate change: Financial risks to Federal and Private Insurers in Coming Decades are Potentially Significant. GAO-07-285. Washington, DC: GAO. http://www.gao.gov/ new.items/d07285.pdf.

Gelbardi, J.L., and S. Harrison. 2005.Invasibility of roadless grasslands: An experimental study of yellow starthistle. Ecological Applications 15:1570-1580

Greenwald, N. 1998.Protection and conservation of roadless areas in the Southwest. Flagstaff, AZ: Southwest Forest Alliance.

Greenway, R. 1996. Wilderness experience and ecopsychology. International Journal of Wilderness 2:26-30.

Gucinski, H., M.J. Furniss, R.R. Ziemer, and M.H. Brookes. 2001. Forest Roads: A Synthesis of 
Scientific Information. General Technical Report PNWGTR-509. Portland, OR: US Department of Agriculture, USDA Forest Service.

Haynes, R.W, and A.L. Horne. 1997. An Assessment of Ecosystem Components in the Interior Columbia Basin and Portions of The Klamath and Great Basins: Economic Assessment of the Basin. General Technical Report PNW-GTR408. Washington, DC: USDA Forest Service.

Heal, G. 2000. Valuing ecosystem services. Ecosystems 3:24-30.

Henjum, M.G., J.R. Karr, D.L. Bottom, D.A. Perry, J.C. Bednarz, S.G. Wright, S.A. Beckwitt, and E. Beckwitt. 1994. Interim Protection for LateSuccessional Forests, Fisheries, and Watersheds: National Forests East of the Cascade Crest, Oregon and Washington. Eastside Forests Scientific Society Panel. Technical Review 94-2. Bethesda, MD:The Wildlife Society.

Huntington, C.W. 1998. Streams and salmonid assemblages within roaded and unroaded landscapes in the Clearwater River Sub-basin, Idaho. In Proceedings of the forest-fish conference: Land management practices affecting aquatic ecosystems, eds. M.K. Brewin and D.M.A. Monida. Calgary, AB: Natural Resources Canada, Canada Forest Service, Northern Forest Center.

Jones, J.A., F.J. Swanson, B.C. Wemple, and K.U. Snyder. 2000. Effects of roads on hydrology, geomorphology, and disturbance patches in stream networks. Conservation Biology 14:76-85.

King, J.G. 1989. Streamflow Responses to Road Building and Harvesting: A comparison with the Equivalent Clearcut Area Procedure. USDA Forest Service Res Paper INT-401, Ogden, UT.

King, J.G. 1993. Sediment production and transport in forested watersheds in the northern rocky mountains. In Proceedings of Technical Workshop on Sediments, Terrene Institute, 13 18, Washington, DC.

Krieger, D. 2001. Economic Value of Forest Ecosystem Services: A Review. Washington, DC: The Wilderness Society.

Loomis, J.B. 1988. Economic Benefits of Pristine Watersheds. Denver, CO: American Wilderness Alliance.

Loomis, J.B., and R. Richardson. 2001. Economic values of the U.S. Wilderness System: Research, evidence to date, and questions for the future. International Journal of Wilderness 7:31-34.

Loomis, J.B. 2005. Updated Outdoor Recreation Use Values on National Forest and Other Public Lands. General Technical Report PNW-GTR-658.

Loucks, C., N. Brown, A. Loucks, and K. Cesareo. 2003. USDA Forest Service roadless areas:
Potential biodiversity conservation reserves. Conservation Ecology 7:2-5

Lugo, A.E., and H. Gucinski. 2000. Function, effects, and management of forest roads. Forest Ecology and Management 133:249-262.

McIntosh, B.A., J.R. Sedell, J.E. Smith, R.C.Wissmar, S.E. Clarke, G.H. Reeves, and L.A. Brown. 1994. Historical changes in fish habitat for select river basins of eastern Oregon and Washington. Northwest Science (Special Issue) 68:36-53.

McIntosh, B.A., J.R. Sedell, R.F.Thurow, S.E. Clarke, and G.L. Chandler. 1995. Historical changes in pool habitats in the Columbia River Basin: Report to the Eastside Ecosystem Management Project. Walla Walla, WA: USDA Forest Service.

Megahan, W.F., and W.J. Kidd. 1972. Effects of logging and logging roads on erosion and sediment deposition from steep terrain. Journal of Forestry 70:136-141.

Miller, W.P., T.C. Piechota, S. Gangopadhyay, and T. Pruitts.2010. Development of streamflow projections under changing climate conditions over Colorado River Basin headwaters. Hydrology and Earth System Sciences 7:5577-5619.

Mohammed, I.N., and D.B. Tarboton. 2008. Watershed Management and Water Production Study for State of Utah: A Report for the Utah Governor's Public Lands Office. Logan, UT: Utah State University.

NRC (National Research Council). 1996. Upstream: Salmon and Society in the Pacific Northwest. Washington, DC: National Academy Press.

NRC. 2000. Watershed Management for Potable Water Supply: Assessing the New York City Strategy. Washington, DC: National Academy Press.

Oechsli, L., and C. Frissell. 2002. Aquatic Integrity Areas: Upper Missouri River Basin. American Wildlands, The Pacific River Council,Yellowstone to Yukon Conservation Initiative, Bozeman MT.

Payne, J.T., A.W. Wood, A.F. Hamlet, R.N. Palmer, and D.P. Lettenmaier. 2004. Mitigating the effects of climate change on the water resources of the Columbia River Basin. Climatic Change 62:233-256.

Petersen, D. 2005. Where the Wildlands are: Colorado. Durango, CO:Trout Unlimited.

Platts, W.S., and R.L. Nelson. 1985. Stream habitat and fisheries response to livestock grazing and instream improvement structures, Big Creek, Utah. Journal of Soil and Water Conservation 40:374-379.

Postel, S.L., and B.H.Thompson, Jr. 2005. Watershed protection: Capturing the benefits of nature's water supply services. Natural Resources Forum 29:98-108.

Raff, D.A., T. Pruitt, and L.D. Brekke. 2009. A framework for assessing flood frequency based on climate projection information. Hydrology and Earth System Sciences 13:2119-2136.

Saunders, S., C. Montgomery,T. Easley, and T. Spencer. 2008. Hotter and drier: The West's changed climate. Washington, DC: The Rocky Mountain Climate Organization and Natural Resources Defense Council.

Schwickert, T., and F. Mauldin. 1997. Salem Cost Impacts from Turbid Water in the North Santiam River in the Aftermath of the 1996 Flood Events. Salem, OR: City of Salem Public Works Department.

Secchi, S., P.W. Gassman, M. Jha, L. Kurkalova, H.H. Feng, T. Campbell, C.L. King. 2005. The cost of clean water: Assessing agricultural pollution reduction at the watershed scale. Ames, IA: Center for Agricultural and Rural Development, Iowa State University. http://cardsrv1.card.iastate.edu/ environment/items/idnr_assess.pdf.

Sedell, J., S. Maitland, D. Dravnieks, M. Copenhagen, and M. Furniss. 2000. Water and the Forest Service. Washington, DC: USDA Forest Service, FS-660.

Seeds, J. 2010. Turbidity Analysis for Oregon Public Water Systems: Water Quality in Coast Range Drinking Water Source Areas. PSW201006. Portland, OR: Oregon Department of Environmental Quality.

Straub, N. 2010. Colorado Submits Final Plan for 4.2M Acres of Roadless Lands. New York Times, April 6, 2010. http://www.nytimes.com/ gwire/2010/04/06/06greenwire-colo-submitsfinal-plan-for-42m-acres-of-roadl-17832.html.

Strittholt, J.R., and D.A. DellaSala. 2001. Importance of roadless areas in biodiversity conservation in forested ecosystems: Case study of the KlamathSiskiyou ecoregion of the United States. Conservation Biology 15:1742-1754.

Strittholt, J.R., D.A. DellaSala, E. Fernandez, G. Heilman, Jr, and P.A. Frost. 2004. Oregon's legacy Wild Forests: Conservation Value of Oregon's Inventoried Roadless Areas. Corvallis, OR: Conservation Biology Institute, World Wildlife Fund, Oregon Natural Resources Council.

Talberth, J., and K. Moskowitz. 1999. The economic case against National Forest logging. Forest Conservation Council, Forest Guardians, National Forest Protection Alliance, Santa Fe, New Mexico. 
Theobald, D.M. 2005. Landscape patterns of exurban growth in the USA from 1980 to 2020 . Ecology and Society 10:32.

Trombulak, S.C., and C.A. Frissell. 2000. Review of ecological effects of roads on terrestrial and aquatic communities. Conservation Biology 14:18-30.

Trout Unlimited. 2004. Where the Wild Lands Are: Idaho. The Importance of Roadless Areas to Idaho's Fish, Wildlife, Hunting and Angling. Pollock, ID: Trout Unlimited. http://www. tu.org/atf/cf/\%7BED0023C4-EA23-43969371-8509DC5B4953\%7D/Roadless_Idaho.pdf.

USFS (USDA Forest Service). 1972. RARE I: Final Environmental Statement: Roadless Area Review and Evaluation. Washington, DC: USDA Forest Service.

USFS. 1979. RARE II: Final Environmental Statement: Roadless Area review and evaluation. Washington, DC: USDA Forest Service.
USFS. 2000. Roadless Area Conservation: Final Environmental Impact Statement. Washington, DC: USDA Forest Service

USFS. 2001. National Forest Visitor Use Monitoring National and Regional Project Results. Washington, DC: USDA Forest Service.

USFS. 2011. Rulemaking for Colorado Roadless Areas Revised Draft Environmental Impact Statement. Washington, DC: USDA Forest Service.

Wemple, B.C., and J.A. Jones. 2003. Runoff production on forest roads in a steep, mountain catchment. Water Resources Research 39:1220. 